\title{
Human Resource Outsourcing: Long Term Operating Performance Effects From The Provider's Perspective
}

\author{
Maureen G. Butler, University of Tampa, USA \\ Carolyn M. Callahan, University of Memphis, USA \\ Rodney E. Smith, California State University Long Beach, USA
}

\begin{abstract}
Human resource $(H R)$ outsourcing research has primarily focused on the client with little attention paid to the service provider. As an initial step in understanding this important stakeholder in the HR outsourcing relationship, this study focuses on the financial performance of $H R$ service firms that publicly announce outsourcing contracts. From the provider's perspective, we investigate firm performance changes subsequent to outsourcing contract announcements, using a sample of 94 publicly available press releases. Our tests show that in the long term, small $H R$ service providers contracted by large client firms experience improvements in operating profitability and margins.
\end{abstract}

Keywords: human resource outsourcing, operating performance, human resource services, return on assets, return on sales

\section{INTRODUCTION}

$\mathcal{O C}$ otwithstanding the challenging economic times, the global human resource outsourcing (HRO) market is expected to increase in value from $\$ 26.8$ billion in 2006 to $\$ 43.7$ billion by 2011 according to Gartner, a global IT research and advisory company (Griffiths, 2008). Public reports indicate that more than $60 \%$ of firms engage in some form of human resource outsourcing (Esen, 2004; Adler, 2003; Dell, 2004). As firms continue to outsource HR services to reduce costs, improve service quality, and enhance core competency (Shen, 2005; Miller, 2008), finding the right supplier is essential to the success of outsourcing contracts (Feeny et al., 2005). To meet the demand for services, an industry of providers is developing. Thus, the focus of potential HRO client firms has shifted from the fundamental decision to outsource to selecting the right provider, according to Jay Rising, President of HR Outsourcing for Hewitt (HROT Staff, 2008).

Clients engaged in long term, high dollar value HR arrangements depend on providers for continuous services for the life of the contract. Thus, they have a stake in the providers' long term success. On the other hand, clients also have an incentive to reap maximum benefits from each contract and are therefore likely to behave in ways that erode margins of providers (Feeny et al., 2005). Academic researchers have paid relatively little attention to the performance consequences for HR service providers (Jenster and Pedersen, 2000; Levina and Ross, 2003; Taylor, 2007). A successful outsourcing arrangement requires the provider accept increased risks in exchange for some benefit (Taylor, 2007), the most obvious, increased revenue. HR service providers also benefit from standardizing processes and thereby achieving economies of scale across clients leading to reduced costs of providing services (Cooke et al., 2005). Revenue growth and lower costs should improve profitability and deliver greater shareholder value (Kaplan and Norton, 2000). Although individual contracts often provide substantial revenue sources, they also signal provider capabilities to other potential clients. Consistent with a signaling argument, Gao (2005) finds that service providers experience significant abnormal returns around contract announcements. However, Gao's sample includes outsourcing providers of a broad range of services, and the analyses do not examine long run operating performance following the positive market reaction. 
In this study, we contribute to the literature by focusing on the providers of HR services. Our employment of archival financial methods and information to address the research questions extends the survey and case study methods commonly used in previous outsourcing research. Human resource service providers are individually important stakeholders in the HRO agreement and collectively form a growing industry (Feeny et al., 2005). In particular, we examine the long term operating performance effects on service providers. Our long term operating performance tests show that small HR service providers contracted by large client firms experience significant improvements in operating profitability.

\section{THEORY AND HYPOTHESIS DEVELOPMENT}

Outsourcing literature traditionally relies on transaction cost economics (TCE) to hypothesize outsourcing decisions and results (Lievens and Corte, 2008). Transaction cost economics proposes that firms consider asset specificity, uncertainty, and frequency of an activity in choosing to perform functions in-house or to contract with an external service provider (Williamson, 1979, 1991). The overall goal is to minimize the sum of transaction and production costs. Asset Specificity is the degree to which an asset can be redeployed to alternative uses and by alternative users without sacrifice of productive value. Uncertainty refers to the expected variation in the demand for activities and the inability to monitor activities. Frequency describes the volume or rate at which activities are performed (Widener and Selto, 1999). Managers of client firms consider these attributes in the outsourcing decision (Walker and Weber, 1984; Roodhooft and Warlop, 1999).

Moreover, the TCE attributes of various HR services also influence the profitability of human resource services firms. For example, firms providing services requiring asset specificity are able to charge higher fees to compensate for the added risk and investment, leading to higher profits (Grossman and Helpman, 2002). While client firms may not be able to justify an investment in technology necessary to deliver state of the art HR services, providers can develop those technological capabilities and leverage them across multiple clients. Similarly, human resource providers might receive higher revenue to compensate for providing services that often vary in activity level or are difficult to monitor. Finally, in performing HR functions which occur frequently, such as payroll processing, human resource service providers can develop efficiencies, and in some cases standardize processes across clients and pool resources to experience economies of scale leading to reduced costs of providing the service (Williamson, 1981; Abraham and Taylor, 1996).

The potential improvements in provider operating performance following a new outsourcing contract may be delayed because of time required to implement the contract and recoup initial investment and set-up costs. According to John Gibson, president for the Convergys HR management business line, the time frame for HRO implementation can exceed 24 months and accounting treatment of these contracts is conservative (Hansen, 2008). Consequently, changes in operating performance are likely to be observed over the long term. In addition to overall operating performance effects, we also expect differential performance effects based on the relative sizes of providers and clients.

HR providers servicing large clients can be expected to handle large transaction volumes of products and provide more types of services, which leads to lower transaction costs and higher profit (Dyer, 1997). Since large firms, in general, should enjoy economies of scale in performing HR services internally, a contracted provider serving a large client can be expected to attain the same economies of scale and resulting profitability effects. Larger HR service providers should have better sourcing capabilities, economies of scale, and economies of scope to help them deliver successful projects and maintain greater expertise (Levina and Ross, 2003; Feeny et al., 2005; Rottman and Lacity, 2008). In an information technology (IT) outsourcing context, Rottman and Lacity (2008) report advantages of contracting with a large supplier, because of the large supplier's greater access to experienced technical personnel, while small suppliers may have difficulty attracting skilled employees and managing projects effectively. Thus, we expect that large HR service provides will perform better in the long term following the HR outsourcing contract. This leads to the following hypothesis:

H1: Large HR service providers will perform better following HR outsourcing contract announcements. 
Conversely, small suppliers offer other benefits to clients that can lead to potential positive wealth effects. Small providers are likely to pay more attention to the client because the client represents a larger portion of their revenues (Feeny et al., 2005; Rottman and Lacity, 2008), especially when the client is a large firm. Additionally, small providers have an incentive to cultivate positive relationships with clients to signal trustworthiness to other potential clients, thereby increasing their future business opportunities (Lievens and Corte, 2008). Small providers are also more likely to offer unique specialized services than large providers, which can enhance their bargaining power and profitability (Grossman and Helpman, 2002). Furthermore, small providers contracting with large clients may be able to leverage their specialized services and the large clients' economies of scale to achieve higher performance. This leads to the following hypotheses:

H2a: HR service providers serving large clients will perform better following HR outsourcing contract announcements.

H2b: Small HR service providers serving large clients will perform better following HR outsourcing contract announcements.

\section{DATA AND METHOD}

We test our hypotheses using a sample of publicly released human resource outsourcing announcements taken from a search on Business Wire using Lexis-Nexis. Of the initial sample of 485 announcements, 201 were for government, privately held, or other provider firms for which firm level financial data was not available on the Compustat database. We eliminated announcements lacking the requisite data, leaving 94 announcements by 67 firms. We carefully reviewed our selected announcements. The announcements, released between 1994 and 2005, specified a variety of HR services, including staffing and hiring, benefits administration, workforce management and employee communications, payroll and payroll tax filing. We also partitioned the sample by client and provider size, the details of which are in Table 1. We divide the sample at the median based on quarterly sales resulting in 46 larger providers and 48 smaller providers. We then categorize clients similarly based on sales for public companies. The "other" category reflects the substantial number of government and not-for-profit organizations that outsource their HR services.

Table I: Number of Human Resource Service Providers and Clients

\begin{tabular}{cccccc}
\hline & & & Clients & \\
& & Large & Small & Other & Total \\
\hline \multirow{3}{*}{ Providers } & Large & 12 & 12 & 22 & 46 \\
& Small & 13 & 10 & 25 & 48 \\
& Total & 25 & 22 & 47 & 94 \\
\hline
\end{tabular}

Table 2: Financial Characteristics of Human Resource Service Providers

\begin{tabular}{|c|c|c|c|c|c|c|c|c|c|}
\hline & \multirow[b]{2}{*}{ Financial characteristic } & \multicolumn{4}{|c|}{ Small Providers } & \multicolumn{4}{|c|}{ Large Providers } \\
\hline & & Mean & Med. & SD & $\mathbf{N}$ & Mean & Med. & SD & $\mathbf{N}$ \\
\hline \multirow{6}{*}{$\begin{array}{l}\text { Pre-announcement } \\
\text { (4 quarters) }\end{array}$} & Sales $(\$ \mathrm{~mm})$ & 69.8 & 30.9 & 73.6 & 188 & $1,441.4$ & 635.5 & $1,376.5$ & 188 \\
\hline & Op income $(\$ \mathrm{~mm})$ & 7.9 & 2.6 & 16.8 & 174 & 222.1 & 99.8 & 202.9 & 178 \\
\hline & Segment count & 1.6 & 1.0 & 1.1 & 188 & 3.5 & 3.0 & 1.7 & 188 \\
\hline & Long term debt $(\$ \mathrm{~mm})$ & 26.9 & 2.5 & 71.5 & 187 & 461.4 & 155.2 & $1,075.4$ & 187 \\
\hline & Market value $(\$ \mathrm{~mm})$ & 646.8 & 379.2 & 843.1 & 188 & $7,743.2$ & $4,696.5$ & $7,422.2$ & 188 \\
\hline & Market-to-book ratio & 3.5 & 2.5 & 2.2 & 176 & 4.9 & 3.4 & 4.1 & 188 \\
\hline \multirow{6}{*}{$\begin{array}{l}\text { Post-announcement } \\
\text { (12 quarters) }\end{array}$} & Sales $(\$ \mathrm{~mm})$ & 82.0 & 52.3 & 77.9 & 491 & $1,498.5$ & 695.4 & $1,465.4$ & 468 \\
\hline & Op income $(\$ \mathrm{~mm})$ & 10.5 & 3.8 & 19.4 & 445 & 227.6 & 100.6 & 210.7 & 465 \\
\hline & Segment count & 1.6 & 1.0 & 1.1 & 515 & 3.5 & 3.0 & 1.7 & 478 \\
\hline & Long term debt $(\$ \mathrm{~mm})$ & 45.3 & 5.6 & 99.9 & 487 & 399.9 & 144.8 & 826.9 & 468 \\
\hline & Market value (\$ mm) & 661.7 & 379.2 & 869.1 & 515 & $7,433.6$ & $4,686.9$ & $7,499.7$ & 478 \\
\hline & Market-to-book ratio & 3.5 & 2.5 & 2.3 & 480 & 5.0 & 3.5 & 4.3 & 478 \\
\hline
\end{tabular}


In Table 2, we provide summary financial characteristics for the HR service providers. The small providers' quarterly sales are less than $\$ 70$ million on average and they typically have only one business segment. They carry some long term debt; the median long term debt pre-announcement is $\$ 2.5$ million and postannouncement is $\$ 5.6$ million. The market seems to view their prospects positively, since they enjoy relatively high market values. Mean (median) market-to-book ratios are 3.5 (2.5) in both periods, consistent with higher growth opportunities. Large providers are about 17 times larger than the small providers on average based on quarterly sales. Large providers typically have three or more business segments, substantially more long term debt, and much higher market values than the small providers do. Their median market-to-book ratios are greater than three, consistent with high growth expectations.

\section{Analysis of long term operating performance effects and firm size}

We test the change in financial performance around the outsourcing announcement using two common measures of operating performance: operating return on assets (ROA), calculated as operating income before depreciation divided by total assets, and operating profit margin (ROS), calculated as operating income before depreciation divided by total revenue. Operating ROA measures a firms' profitability relative to their total assets. Operating profit margin measures a firms' profit per dollar of revenue. These are both standard measures of operating profitability closely related to operating cash flow, since they do not include depreciation. HR providers have substantial depreciation charges due to the capital intensive nature of the business, so including depreciation could mask otherwise positive performance.

We form two periods around each HR outsourcing contract announcement. The first period is the four quarters prior to the announcement. The second period is the 12 quarters following the announcement. We employ 12 quarters following the announcement to allow the providers to recoup initial start up costs and establish a relatively steady performance state. We analyze changes in performance following the contract compared to performance prior to the contract using the following models:

$$
\begin{aligned}
\text { Op_metric }= & b_{0}+b_{1} \text { small_p_after }+b_{2} \text { large_p_after }+b_{3} \text { small_c_after }+b_{4} \text { large_c_after } \\
& +b_{5} \text { pre_contract_size }+b_{6} \text { pre_contract_op_metric }+e \\
\text { Op_metric }= & b_{0}+b_{1} \text { small_p_after }+b_{2} \text { large_p_after }+b_{3} \text { small_c_after }+b_{4} \text { large_c_after } \\
& +b_{5} \text { small_p_after } x \text { large_c_after }+b_{6} \text { large_p_after } x \text { small_c_after }+b_{7} \text { pre_contract_size } \\
& +b_{8} \text { pre_contract_op_metric }
\end{aligned}
$$

Op_metric equals either operating ROA or profit margin. Small_p_after and large_p_after are dummy variables that indicate small or large providers in the period after the contract announcement. We divide the sample at the median based on total sales to form the small and large dummy variables. Similarly, small_c_after and large_c_after are dummy variables that indicate small or large clients after the contract announcement. A significant positive coefficient for these variables indicates higher performance following the contract announcement. Small_p_after $x$ large_c_after and large_p_after x small_c_after are interaction terms that measure the performance effect of the particular combination of provider and client. Pre_contract_size is the mean total assets or total sales (log transformed) for the four quarters prior to the announcement for each firm. Pre_contract_op_metric is the mean ROA or profit margin for the four quarters prior to the announcement for each firm. These two variables control for differences in size and performance prior to the outsourcing contract. We also control for industry, using three-digit SIC, in the multivariate analysis of Equations 1 and 2. Since we use panel data, we adjust for potential heteroskedasticity and serial correlation with Newey-West standard errors (StataCorp, 2007).

\section{TEST RESULTS}

\section{Univariate Analysis}

To determine whether HRO providers experience long term operating performance improvements, we examine the mean quarterly operating return on assets (ROA) and operating profit margins (ROS) around the outsourcing announcements. Figure 1 presents a chart of quarterly operating ROA and shows that with the exception 
of small providers serving large clients, there is little change in performance following the contract announcements. However, the performance of small providers contracting with large clients increases substantially in the second year after the contract announcement and more than three times the pre-contract levels in the third year after the announcement.

Figure 2 presents a chart of quarterly operating profit margins that shows similar performance patterns. Again, the small providers contracting with large clients experience the greatest increase. In general, large providers have higher performance before the contract and experience little change in performance following the contract. The difference in operating ROA (average operating ROA is approximately 3\%) compared to profit margins (average operating profit margin is approximately 11\%) demonstrates the capital intensive nature of the HR outsourcing industry.

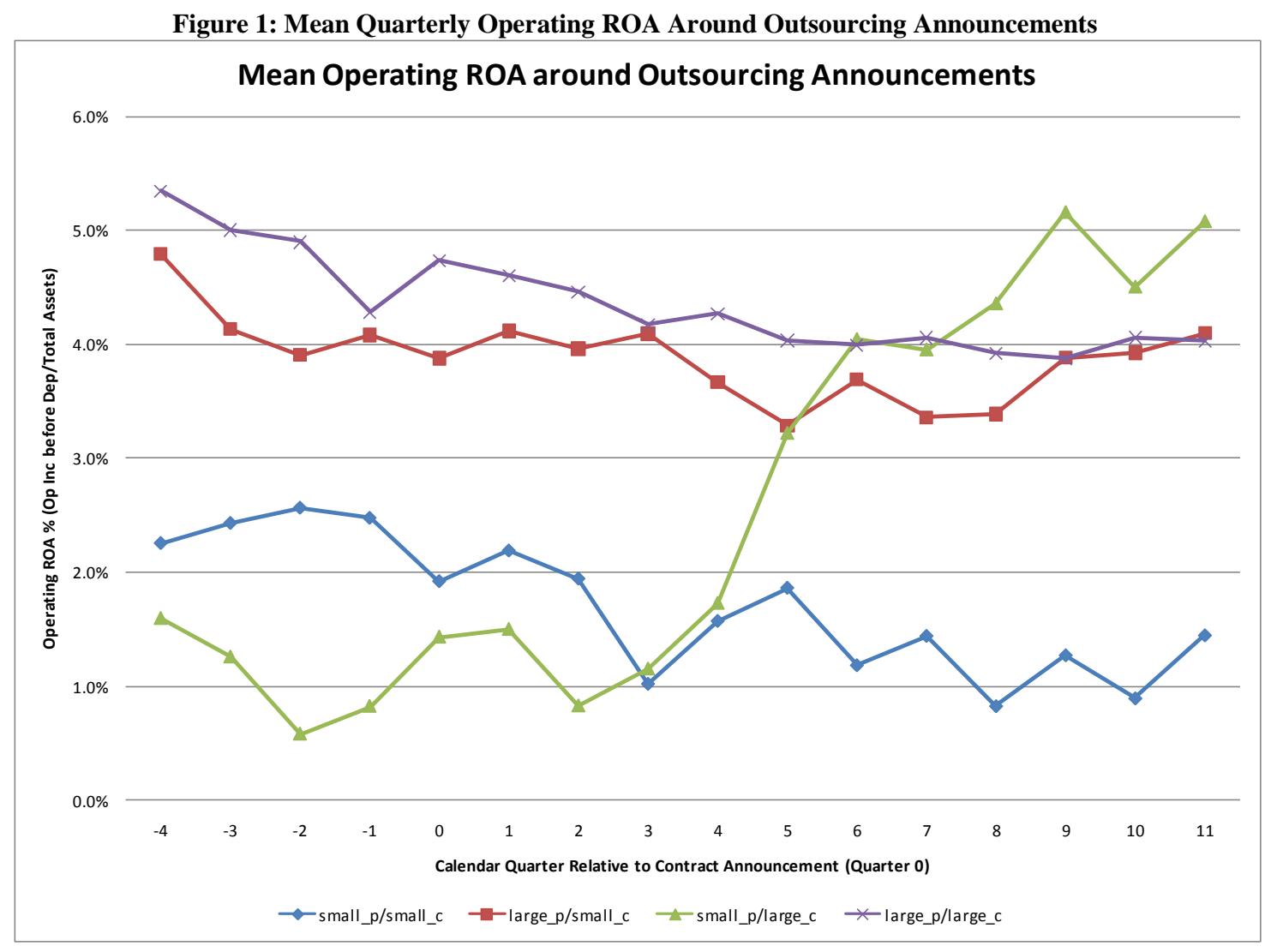

Only small providers contracting with large clients see an increase in operating performance after the contract announcements. Untabulated results show that the average increase in operating ROA for small providers with large clients is $1.9 \%(\mathrm{t}=2.29, \mathrm{p}<0.02$, one-tailed test $)$, and the corresponding increase in profit margins is $9.3 \%(\mathrm{t}=2.70, \mathrm{p}<0.01$, one-tailed test $)$. On average, large providers have $1.7 \%$ higher operating ROA and $7.4 \%$ higher profit margins than small providers following the contract announcements. Overall, large providers outperform small providers and small HRO providers experience differential operating performance benefits when serving large clients. These results are consistent with hypotheses $\mathrm{H} 1, \mathrm{H} 2 \mathrm{a}$, and $\mathrm{H} 3 \mathrm{~b}$ and suggest that small HR service providers have the potential to improve overall operating performance, rivaling that of larger providers, by contracting with larger clients. 
Figure 2: Mean Quarterly Operating Profit Margins (ROS) Around Outsourcing Announcements

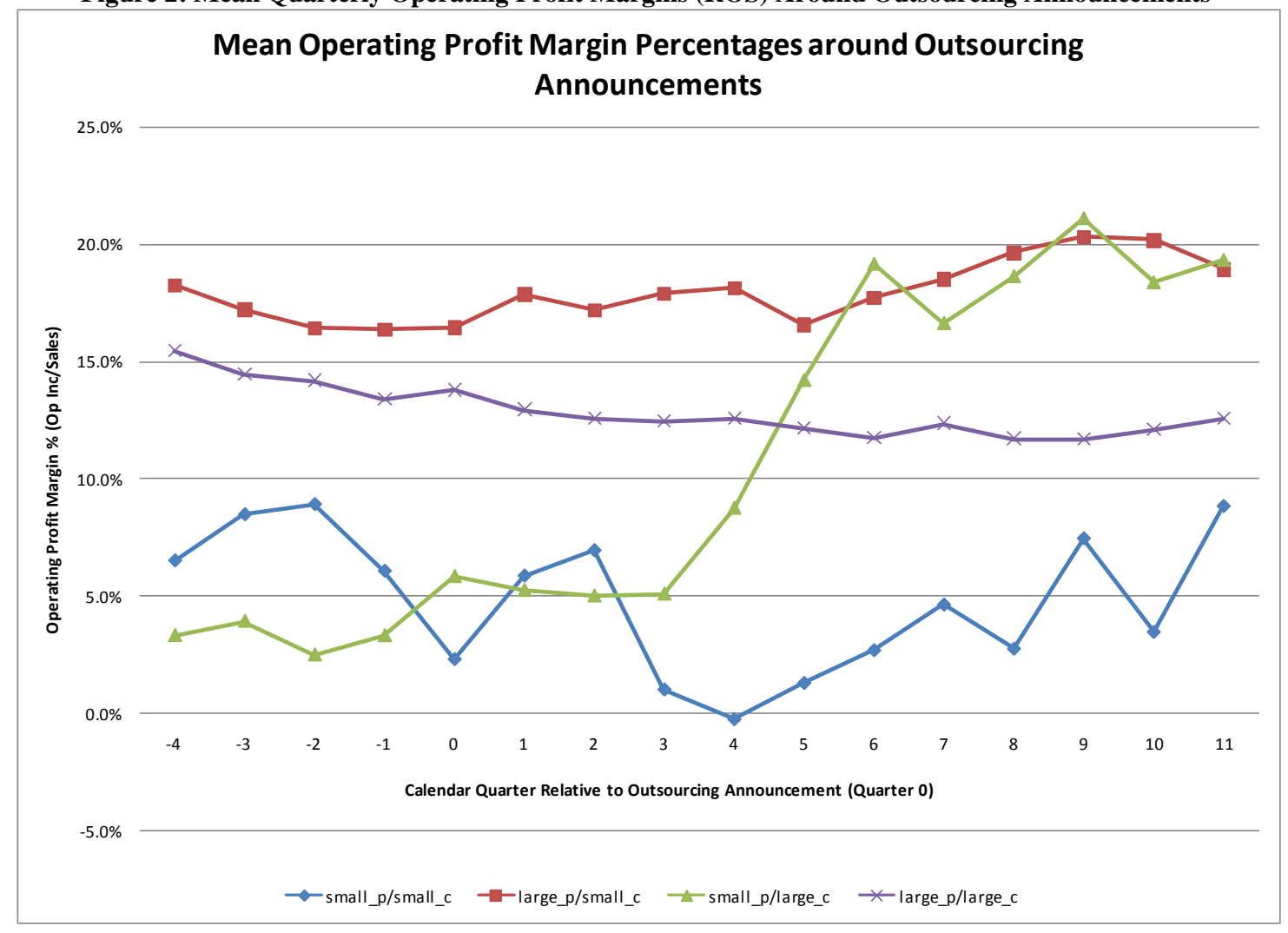

\section{Multivariate Analysis}

Although we observe significant improvement in ROA and ROS following the outsourcing announcements for small providers contracting with large clients in our univariate analyses, multivariate analysis allows us to control for other factors that potentially influence overall operating performance. Table 3 presents a multivariate analysis of the changes in operating performance following the contract announcements. Operating ROA and ROS variables were winsorized $1 \%$ at each end of the distribution to limit the influence of outliers. Columns 1 and 2 present results for operating ROA based on Equations 1 and 2, respectively. Columns 3 and 4 present similar results for operating profit margins. Observations with studentized residuals greater than 3 standard deviations from the mean were eliminated. By construction, these results focus on changes in performance, since the dummy variables all equal 0 for the four quarters prior to the contract announcements. These results show that large providers see a modest but significant slip in operating performance following the contract announcements and small providers experience no increase in performance.

Columns 2 and 4 examine the interaction of small provider with large client, as well as large provider with small client. The coefficient on the small_p_after x large_c_after variable is significant, showing that on average, this combination performs better than other combinations or either small providers or large clients in general. These results confirm hypothesis $\mathrm{H} 2 \mathrm{~b}$ indicating that small $\mathrm{HR}$ service providers serving large clients perform better following HR outsourcing contract announcements. 
Table 3: Regression Analysis of Operating ROA and Profit Margins around Outsourcing Announcements

\begin{tabular}{lcccc}
\hline Variables & \multicolumn{2}{c}{ Operating ROA } & \multicolumn{2}{c}{$\begin{array}{c}\text { Operating Profit Margin (ROS) } \\
\text { (3) }\end{array}$} \\
& Coef.(t-stat) & $\begin{array}{c}(\mathbf{2}) \\
\text { Coef. (t-stat) }\end{array}$ & $\begin{array}{c}\text { Coef. (t-stat) } \\
\text { Coef. (t-stat) }\end{array}$ \\
\hline Constant & $-0.004(1.00)$ & $-0.007(1.53)$ & $0.270(19.22)$ & $0.254(18.57)$ \\
Small_p_after & $0.002(0.68)$ & $-0.000(0.13)$ & $0.012(1.50)$ & $0.004(0.50)$ \\
Large_p_after & $-0.007(3.99)$ & $-0.006(2.82)$ & $-0.016(2.97)$ & $-0.009(1.62)$ \\
Small_c_after & $-0.005(2.69)$ & $-0.004(1.63)$ & $-0.013(1.79)$ & $-0.027(2.30)$ \\
Large_c_after & $0.003(1.34)$ & $-0.004(1.54)$ & $0.026(3.36)$ & $-0.018(2.98)$ \\
Small_p_after x Large_c_after & & $0.016(3.43)$ & & $0.108(6.20)$ \\
Large_p_after x Small_c_after & & $-0.002(0.69)$ & & $0.023(1.78)$ \\
Pre_contract_size & $0.001(1.03)$ & $0.001(1.21)$ & $0.003(1.21)$ & $0.004(1.96)$ \\
Pre_contract_ROA/ROS & $0.125(14.18)$ & $0.127(14.59)$ & $0.621(16.27)$ & $0.630(18.42)$ \\
Observations & 1220 & 1220 & 1220 & 1220 \\
Adjusted R-square & 0.54 & 0.54 & 0.65 & 0.69 \\
\hline
\end{tabular}

\section{Discussion}

When a firm decides to outsource its human resource services, it must consider the cost and benefits of doing so, with the selection of the provider being a critical factor in the success of the outsourcing arrangement. This study examines human resource outsourcing from the perspective of the provider who also must consider costs and benefits before agreeing to serve a particular client. Prior HR outsourcing literature rarely focuses on this important, but critical stakeholder in the outsourcing contract.

Our results provide insight into factors influencing the profitability of HR service firms. Small providers serving large clients show significantly improved operating performance in the long term, suggesting that small providers engaging large clients are able to experience benefits resulting from a trusting relationship with the client (Lievens and Corte, 2008) and from exploiting economies of scale. In this study, we extend HRO research by examining overall performance metrics of human resource service providers as well as the provider/client pairing as suggested by Lievens and Corte (2008). With a preponderance of outsourcing research focused on qualitative factors regarding the decision and perceptions of participants, we see an opportunity and a need to study further the quantitative factors driving the decision and the quantitative results once the decision has been implemented. To understand fully the actual costs and benefits of human resource outsourcing requires access to information such as HR staff salaries, HR information technology investment costs and human resource operation productivity.

As with all research, this study has limitations. The small sample size is partly a result of the sample composition. We use publicly released outsourcing announcements, therefore, our sample does not include providers who entered into new contracts but did not publicly announce either by choice or because of the client's prohibition. Our analyses require financial information available only for publicly traded firms, eliminating an important segment of the HR outsourcing providers as well as a number of clients from our sample who operate as private, not-for-profit or government organizations. Finally, because of the small sample size, we are unable to test the effect of the type of HRO service provided on operating performance.

In spite of these limitations, this study offers useful information for human resource services firm managers regarding factors influencing long term operating performance. In particular, our tests show that small providers serving large clients experience improved long term operating performance. This initial study examining overall performance effects for HRO providers is foundational to understanding more specific operational effects experienced by both providers and clients engaging in new outsourcing contracts.

\section{AUTHOR INFORMATION}

Maureen G. Butler is an assistant professor in the John H. Sykes College of Business at the University of Tampa, Tampa, FL. She earned a PhD in accounting from the University of Arkansas in 2006. Her current research is focused on the performance effects of outsourcing, alliances and the defense industry. 
Carolyn M. Callahan, KPMG Distinguished Professor of Accounting and Director of the School of Accountancy at the University of Memphis, earned a Ph.D. from Michigan State University. Her research interests focus on analytical and empirical examination of models that link accounting information to equilibrium prices in aggregate markets. She has published research in the Accounting Review, Journal of Accounting Research, Contemporary Accounting Research, Accounting Horizons, Review of Quantitative Finance and Accounting and the Journal of Accounting Literature.

Rodney E. Smith is an associate professor in the College of Business Administration at California State University Long Beach. He received a Ph.D. in accounting from the University of California, Irvine in 2000. His current research involves alliances, technology, and firm performance. He has published research in the The Accounting Review, Journal of Management Accounting Research and the Journal of Information Systems.

\section{REFERENCES}

1. Abraham, K. G., and S. K. Taylor. 1996. Firms' Use of Outside Contractors: Theory and Evidence. Journal of Labor Economics 14 (3):394-424.

2. Adler, P. S. 2003. Making the HR Outsourcing Decision. MIT Sloan Management Review 45 (1):52-61.

3. Cooke, F. L., J. Shen, and A. McBride. 2005. Outsourcing HR as a Competitive Strategy? A Literature Review and an Assessment of Implications. Human Resource Management 44 (4):413-432.

4. Dell, D. J. 2004. HR Outsourcing Benefits, Challenges, and Trends: The Conference Board.

5. Dyer, J. H. 1997. Effective Interfirm Collaboration: How Firms Minimize Transaction Costs and Maximize Transaction Value. Strategic Management Journal 18 (7):535-556.

6. Esen, E. 2004. SHRM Human Resource Outsourcing Survey Report: Society for Human Resource Management.

7. Feeny, D., M. Lacity, and L. P. Willcocks. 2005. Taking the Measure of Outsourcing Providers. MIT Sloan Management Review 46 (3):41.

8. Gao, N. 2005. Firm value: Market Reaction to Corporate Outsourcing Transactions: University of Pittsburgh, Pittsburgh, PA.

9. Griffiths, S. 2008. A Cold, Hard Look at the Numbers. The Sunday Times, March 9, 2008, 4.

10. Grossman, G. M., and E. Helpman. 2002. Integration Versus Outsourcing in Industry Equilibrium. The Quarterly Journal of Economics February:85-120.

11. Hansen, F. 2008. The Mega-Deals: An Exclusive Club. Workforce Management, March 17, 2008.

12. HROT Staff. 2008. Executive Roundtable: Providers Assess the HRO Market. In HRO Today.

13. Jenster, P. V., and H. S. Pedersen. 2000. Outsourcing - Facts and Fiction. Strategic Change 9 (3):147-154.

14. Kaplan, R. S., and D. P. Norton. 2000. The Strategy-Focused Organization. Boston, MA: Harvard Business School Press.

15. Levina, N., and J. W. Ross. 2003. From the Vendor's Perspective: Exploring the Value Proposition in Information Technology Outsourcing. MIS Quarterly 27 (3):331-364.

16. Lievens, F., and W. D. Corte. 2008. Development and Test of a Model of External Organizational Commitment in Human Resources Outsourcing. Human Resource Management 47 (3):559-579.

17. Miller, J. 2008. A Total Benefits Strategy is a Valuable Approach in HR Outsourcing. Employment Relations Today 34 (4):55.

18. Roodhooft, F., and L. Warlop. 1999. On the Role of Sunk Costs and Asset Specificity in Outsourcing Decisions: A Research Note. Accounting, Organizations and Society 24 (4):363.

19. Rottman, J. W., and M. C. Lacity. 2008. A US Client's Learning from Outsourcing IT Work Offshore. Information Systems Frontiers 10:259-275.

20. Shen, J. 2005. Human Resource Outsourcing: 1990-2004. Organisational Transformation and Social Change 2 (3): 275.

21. Stata Statistical Software: Release 10. StataCorp LP, College Station, TX.

22. Taylor, H. 2007. Outsourced IT Projects from the Vendor Perspective: Different Goals, Different Risks. Journal of Global Information Management 15 (2):1.

23. Walker, G., and D. Weber. 1984. A Transaction Cost Approach to Make-or-Buy Decisions. Administrative Science Quarterly 29 (3):373-391. 
24. Widener, S. K., and F. H. Selto. 1999. Management Control Systems and Boundaries of the Firm: Why do Firms Outsource Internal Auditing Activities? Journal of Management Accounting Research 11:45-73.

25. Williamson, O. E. 1979. Transaction-Cost Economics: The Governance of Contractual Relations. The Journal of Law and Economics 22 (October):233-261.

26. Williamson, O.E. 1981. The Economics of Organization: The Transaction Cost Approach The American Journal of Sociology 87 (3):548-577.

27. Williamson, O.E. 1991. Comparative Economic Organization: The Analysis of Discrete Structural Alternatives. Administrative Science Quarterly 36:269-296. 
NOTES 